\title{
Penentuan Skema Negosiasi Tarif Jasa Giling Clinker menjadi Semen dari Perspektif Produsen Semen dan Pemilik Grinding Plant
}

\author{
Mira Ammalia dan Yudha Andrian Saputra \\ Teknik Industri, Fakultas Teknologi Industri, Institut Teknologi Sepuluh Nopember (ITS) \\ J1. Arief Rahman Hakim, Surabaya 60111 Indonesia \\ e-mail: yandrian@ie.its.ac.id
}

\begin{abstract}
Abstrak- Keseluruhan proses produksi semen dapat diolah oleh full plant. Proses yang bisa dilaksanakan terpisah merupakan pengolahan dari clinker menjadi semen menggunakan grinding plant. Konsumsi semen nasional diproyeksikan akan meningkat, sehingga Perseroan berencana menyelesaikan proyek pembangunan grinding plant di Cigading, Banten untuk mempertahankan pangsa pasar. Grinding plant yang pernah dibangun dikelola oleh Perseroan. Namun, investasi grinding plant dipengaruhi banyak faktor ketidakpastian sehingga memiliki risiko tinggi. Untuk meminimumkan risiko dan memenuhi kebutuhan pendanaan investasi grinding plant melalui dana eksternal (pihak ketiga) bagi Perseroan, muncul sebuah usulan skema bisnis dimana grinding plant dikelola oleh pihak ketiga sehingga muncul profil skema negosiasi yang menghasilkan transaksi berupa tarif jasa giling semen. Penelitian akan membantu Perseroan dan Pihak Ketiga menentukan profil skema negosiasi yang sesuai melalui perspektif manfaat ekonomis keberadaan grinding plant bagi kedua belah pihak.

Range skema negosiasi tarif yang feasible bagi kedua belah pihak terletak pada $R p$ 304.000,- hingga Rp 328.000,- dengan titik keseimbangan Rp 328.000,-/ton semen. Titik keseimbangan merupakan salah satu pertimbangan dalam penentuan tarif jasa giling semen yang sebaiknya diambil. Pergeseran tarif tergantung dari pihak mana yang mau mengalah dengan memperoleh nilai manfaat ekonomis (NPV) lebih sedikit dibandingkan dengan pihak lainnya.
\end{abstract}

Kata Kunci-Semen, Skema Negosiasi, Studi Kelayakan, Transshipment Problem.

\section{PENDAHULUAN}

$P^{\prime}$ ROSES produksi semen dimulai dari penambangan bahan mentah (quarry) lalu dicampur dengan komponen - komponen lain sesuai proporsinya untuk diproses ke tahap penggilingan. Dilakukan pemanasan mulai di preheater hingga di dalam kiln membentuk kristal clinker. Clinker ini didinginkan kemudian dihaluskan menggunakan grinding mill, menghasilkan semen siap kemas lalu dijual ke konsumen. Keseluruhan proses produksi semen dapat diolah oleh full plant. Proses yang bisa dilaksanakan terpisah merupakan pengolahan dari clinker menjadi semen menggunakan grinding plant. Sebelumnya, Perseroan pernah membangun grinding plant sebagai salah satu strategi dalam peningkatan kapasitas produksi dalam menjaga ketersediaan pasokan.

Konsumsi semen nasional selama beberapa tahun terakhir menunjukkan pertumbuhan positif sebesar 14,5\% pada tahun 2012 , serta $5,5 \% ; 3,3 \%$ dan $0,87 \%$ masing - masing pada tahun 2013, 2014 dan 2015. Meskipun pada tahun 2015 konsumsi semen nasional mengalami penurunan, proyeksi dari lembaga ekonomi nasional dan internasional memprediksikan perekonomian di Indonesia di tahun 2016 akan tumbuh lebih baik menjadi 5,3\% dari 4,79\%. Pertumbuhan ekonomi Indonesia didominasi oleh konsumsi domestik dan kegiatan investasi, sehingga realisasi proyekproyek infrastruktur dasar dan kebijakan percepatan infrastruktur dari pemerintah yang efektif dan efisien, seperti pembangunan jalan, bendungan, pelabuhan dan ketenagalistrikan diharapkan akan memberi dampak terhadap perbaikan ekonomi. Sehingga, proyeksi pertumbuhan ekonomi secara tidak langsung akan memberikan dampak terhadap industri persemenan berupa peningkatan permintaan pasar yang diperkirakan akan tumbuh $5-7 \%$.

\section{PERTUMBUHAN PASAR SEMEN INDONESIA}

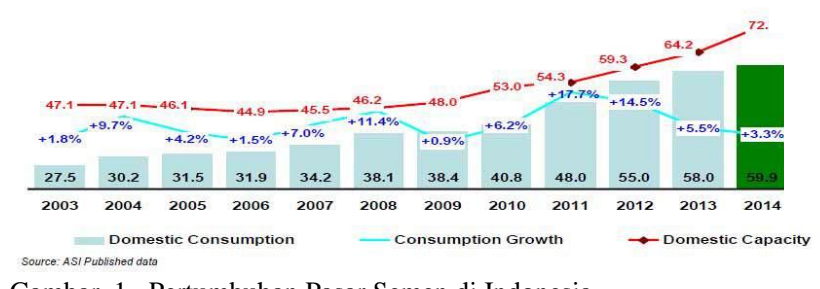

Gambar. 1. Pertumbuhan Pasar Semen di Indonesia.

Melihat konsumsi semen nasional yang diproyeksikan akan meningkat di masa mendatang, Perseroan memiliki rencana untuk menyelesaikan proyek pembangunan grinding plant di Cigading, Banten untuk mempertahankan pangsa pasar. Pembangunan fasilitas grinding plant memiliki nilai strategis dalam pemanfaatan slag powder sisa dari Krakatau Posco. Dimana, grinding plant dapat memanfaatkan slag powder yang ada sebagai campuran clinker dalam pembuatan semen sehingga mampu menurunkan proporsi penggunaan clinker dari yang awalnya 75-80 \% menjadi hanya $55 \%$. 


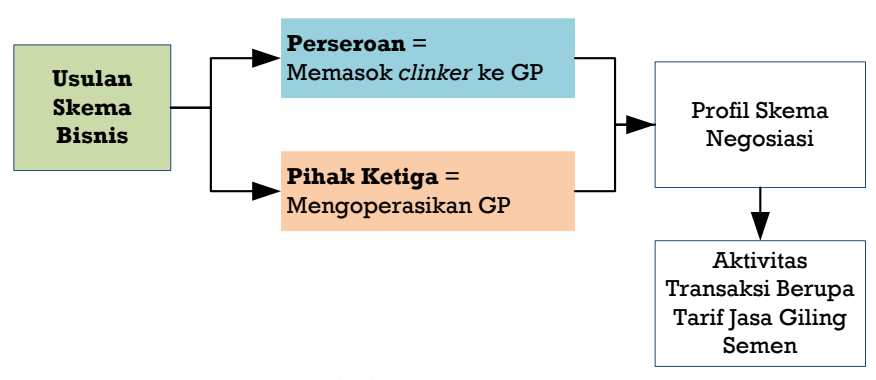

Gambar. 2. Usulan Skema Bisnis.

Kondisi yang ada saat ini, grinding plant yang pernah dibangun sebelumnya dikelola oleh Perseroan. Namun, Kelayakan investasi grinding plant dipengaruhi oleh banyak faktor ketidakpastian, seperti distribution cost, production cost, selling price dan demand nasional sehingga memiliki risiko tinggi. Selain itu, Perseroan saat ini telah dan sedang merealisasikan berbagai program pengembangan usaha melalui beragam kegiatan investasi sehingga perlu adanya penggalian sumber dana eksternal. Oleh karena itu, untuk meminimumkan risiko dan memenuhi kebutuhan pendanaan investasi grinding plant melalui dana eksternal (pihak ketiga) bagi Perseroan, muncul sebuah usulan skema bisnis dimana grinding plant dikelola oleh pihak ketiga sehingga muncul profil skema negosiasi berbentuk tarif jasa giling semen. Penelitian akan membantu Perseroan dan Pihak Ketiga menentukan profil skema negosiasi yang sesuai melalui perspektif manfaat ekonomis keberadaan grinding plant bagi kedua belah pihak.

\section{URAIAN PENELITIAN}

\section{A. Perumusan Konsep Skema Bisnis}

Penelitian diawali dengan adanya usulan skema bisnis, dimana grinding plant dikelola oleh pihak ketiga dan Perseroan sebagai pihak yang memasok clinker untuk diolah di grinding plant. Adanya usulan skema bisnis menyebabkan munculnya profil skema negosiasi antara kedua belah pihak berupa aktivitas transaksi dalam bentuk tarif jasa giling semen.

Untuk memperkuat profil skema negosiasi, maka perlu dilakukan penentuan manfaat ekonomis keberadaan grinding plant bagi kedua pihak, yaitu Perseroan dan pihak ketiga selaku pengelola grinding plant. Pemanfaatan slag powder sisa dari Krakatau Posco mampu menghemat penggunaan clinker dari yang awalnya 1 ton clinker dapat menghasilkan 1,25 ton semen, naik menjadi menjadi 1,82 ton semen sehingga berujung pada penghematan biaya produksi dan penambahan keuntungan penjualan bagi Perseroan. Namun di sisi lain, keberadaan grinding plant juga merubah sistem distribusi Perseroan sehingga ada kemungkinan penambahan biaya distribusi yang harus dikeluarkan. Adanya tarif jasa giling semen yang harus dikeluarkan oleh Perseroan dalam memproses clinker di grinding plant juga menjadi salah satu pertimbangan. Maka dilakukan perbandingan keuntungan yang diperoleh Perseroan dengan dan tanpa adanya grinding plant. Incremental benefit yang diperoleh Perseroan dengan adanya grinding plant ditetapkan sebagai manfaat ekonomis bagi Perseroan.

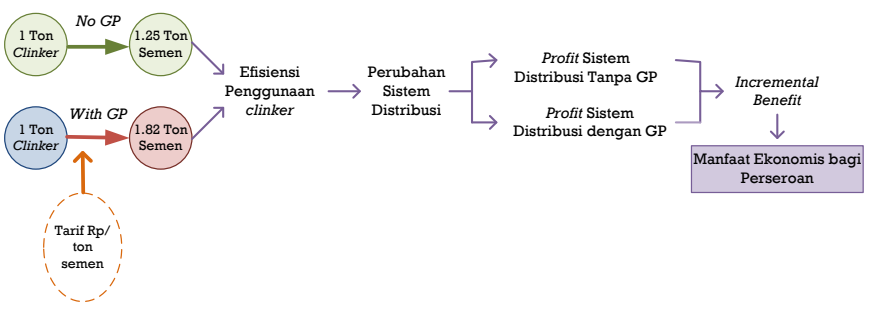

Gambar. 3. Manfaat Ekonomis Keberadaan Grinding Plant bagi Perseroan.

Adanya profil skema negosiasi memunculkan aktivitas transaksi antara Perseroan dan pihak ketiga, dimana transaksi berupa tarif jasa giling semen (Rp/ton) yang diproduksi di grinding plant. Tarif jasa giling semen dikalikan dengan jumlah semen yang dipesan oleh Perseroan merupakan pemasukkan (revenue) bagi pihak ketiga. Revenue berujung pada NPV indikator kelayakan investasi grinding plant bagi pihak ketiga sehingga manfaat ekonomis keberadaan grinding plant bagi pihak ketiga merupakan NPV indikator kelayakan.

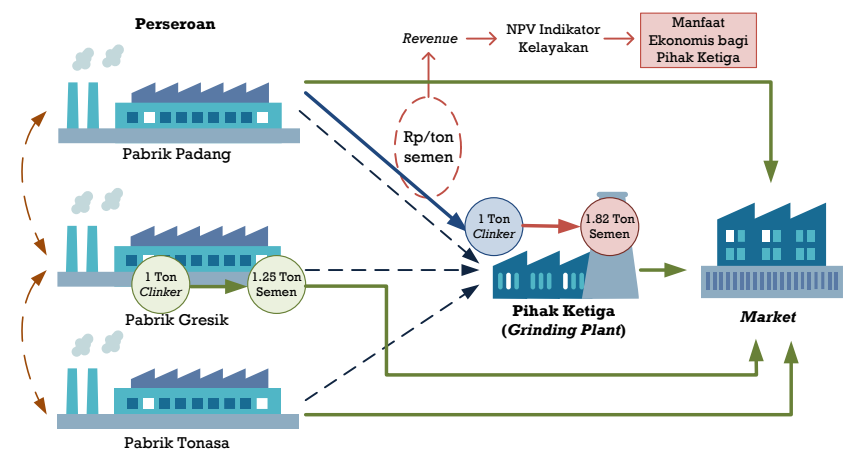

Gambar. 4. Manfaat Ekonomis Keberadaan Grinding Plant bagi Pihak Ketiga

Untuk mengatasi beberapa risiko yang mungkin muncul dengan adanya usulan skema bisnis, maka dirancang sebuah profil skema negosiasi bagi kedua belah pihak yang diturunkan dalam suatu perjanjian. Bagi Perseroan [1] Perseroan diharuskan memasok clinker dan memesan semen sesuai dengan kapasitas terpasang maksimum grinding plant setiap tahunnya. [2] Pasokan clinker datang dari salah satu dari tiga pabrik milik Perseroan, dimana pabrik pemasok dapat berubah setiap tahunnya. [3] Distribution cost pasokan clinker dari pabrik ke grinding plant ditanggung oleh Perseroan. [4] Distribution cost dari grinding plant ke pasar tujuan menggunakan FOT (Free On Truck) mulut pabrik, dimana biaya ditanggung oleh konsumen. [5] Tarif jasa giling semen yang ditetapkan, belum termasuk dengan PPn (Pajak Pertambahan Nilai). Sedangkan bagi pihak ketiga yaitu [1] Pihak ketiga diharuskan mampu memproduksi semen sesuai dengan kapasitas maksimum grinding plant. [2] Pihak ketiga berkewajiban menanggung seluruh biaya investasi dan biaya operasional dalam pengelolaan grinding plant.

\section{B. Perhitungan Manfaat Ekonomis bagi Pihak Ketiga}

Input variable untuk perhitungan manfaat ekonomis adanya grinding plant bagi pihak ketiga merupakan tarif jasa 
giling semen (Rp/ton), biaya investasi, biaya bahan baku, biaya cement bags (Bags/ton), biaya electricity (Rp/Kwh), biaya umum dan sewa (fixed cost), maintenance cost (Rp/ton), biaya manpower (Rp/ton) dan biaya HGG (Rp/ton).

Perhitungan manfaat ekonomis untuk pihak ketiga dilakukan dengan analisis kelayakan investasi dari grinding plant. Dimulai dari pendefinisian investasi, revenue, dan expenditure. Investasi nantinya akan digunakan sebagai input dalam proyeksi. Revenue yang dihasilkan didapatkan dari hasil pembayaran akan penggunaan jasa giling semen, dimana pembayaran dilakukan oleh Perseroan sebesar tarif dikalikan dengan jumlah semen yang diproduksi grinding plant. Pada perhitungan NPV awal, tarif jasa giling semen ditetapkan base nilainya terlebih dahulu sebelum diskenariokan dengan menggunakan fitur goal seek pada Ms. Excel. Dimana dicari tarif jasa giling semen yang menghasilkan NPV indikator kelayakan sama dengan nol, yaitu sebesar Rp 303.931,-/ton semen. Hasil dari goal seek tersebut kemudian dibulatkan ke atas sehingga diperoleh batas bawah tarif jasa giling semen yang feasible bagi pihak ketiga sebesar Rp 304.000,-/ton semen.

Expenditure merupakan pengeluaran yang dikeluarkan setiap tahunnya yaitu berupa biaya operasional. Biaya operasional terdiri atas biaya produksi, biaya persediaan awal barang jadi dan biaya persediaan akhir barang jadi. Biaya produksi terdiri atas variable cost dan fix cost. Dimana komponen variable cost adalah biaya bahan baku, electricity, biaya cement bags, manpower, maintenance cost, dan biaya HGG (Hot Gass Generator. Sedangkan pada fixed cost terdiri atas biaya umum dan sewa, serta biaya penyusutan (depresiasi).

Proyeksi pada penelitian terdiri atas laporan laba rugi, arus kas, neraca, dan arus kas bebas. Input dari laporan laba rugi berupa revenue dan biaya operasional. Arus kas diperoleh dari tiga (3) transaksi utama, yaitu transaksi operasional, investasi dan transaksi keuangan. Transaksi operasional melibatkan penerimaan revenue, serta pengeluaran berupa biaya yang dikeluarkan untuk bahan baku, biaya produksi lainnya dan pajak pendapatan. Transaksi investasi pada grinding plant merupakan biaya yang dikeluarkan untuk investasi pembangunan grinding plant. Transaksi keuangan terdiri atas cash inflow dan cash outlow. Output dari ketiga transaksi utama tersebut akan menghasilkan arus kas bersih, sehingga dapat diperoleh nilai kumulatif saldo akhir kas. Dimana nilai kumulatif tersebut nantinya akan dijadikan salah satu input proyeksi neraca.

Neraca membandingkan antara total aset lancar dan total modal (equity dan liability). Aset lancar termasuk di dalamnya nilai kumulatif saldo akhir kas, nilai piutang (account receivable), nilai persediaan bahan mentah (raw material inventory), nilai persediaan barang di proses (work in process inventory), nilai persediaan barang jadi (finished goods inventory), nilai investasi dan nilai kumulatif penyusutan. Sedangkan untuk modal terdiri atas modal sendiri (equity) dan hutang dagang (liability). Arus kas bebas menampilkan inflow dan outflow yang terjadi pada grinding plant, dimana inflow diperoleh dari nett profit (pendapatan setelah pajak) dan depresiasi. Sedangkan outflow didapat dari investasi dan modal kerja.
Empat proyeksi tersebut kemudian digunakan untuk menghitung indikator kelayakan investasi grinding plant. Kemudian dilihat indikator IRR, NPV, dan payback period apakah memenuhi kriteria kelayakan atau tidak. Dengan tarif sebesar Rp 304.000,-/ton semen diperoleh indikator kelayakan NPV sebesar Rp 914,- (Juta) dan IRR 12,720\%.

\section{Perhitungan Manfaat Ekonomis bagi Perseroan}

Manfaat ekonomis adanya grinding plant bagi Perseroan adalah berupa incremental benefit. Perhitungan dilakukan dengan perancangan model optimasi untuk sistem distribusi pada Perseroan dimulai dari pembuatan model konseptual (influence diagram), model software LINGO lalu validasi dan verifikasi. Tujuannya untuk menentukan alokasi distribusi maksimum baik dalam kondisi tanpa grinding plant dan kondisi dengan adanya grinding plant. Selain itu, model distribusi juga dibutuhkan untuk menentukan full plant mana yang dianggap sebagai sourcing terbaik ke grinding plant serta memproyeksikan alokasi distribusi semen nasional selama masa operasional.

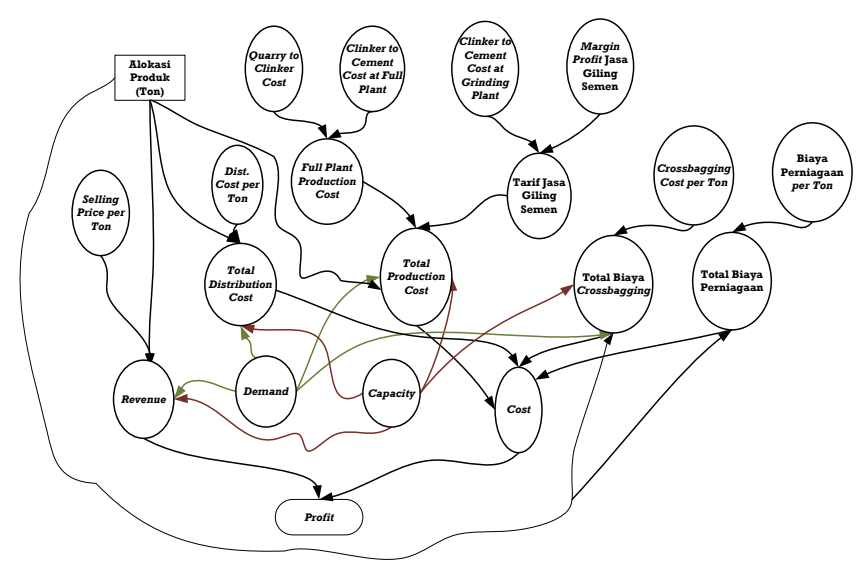

Gambar. 5. Influence Diagram Model Distribusi Perseroan.

Running model optimasi dilakukan dengan fungsi tujuan maksimasi biaya pada kondisi tanpa dan dengan grinding plant. Hasil dari running model optimasi dijadikan dasar dalam perhitungan NPV kedua kondisi. NPV dihitung menggunakan nilai incremental benefit hasil running model optimasi selama 20 tahun. Pada kondisi dengan adanya grinding plant, perhitungan NPV juga harus mempertimbangkan tarif jasa giling semen yang ditetapkan. Input variable perhitungan manfaat ekonomis keberadaan grinding plant bagi Perseroan diantaranya biaya pokok produksi (HPP), biaya distribusi (Distribution Cost), harga jual (Selling Price), crossbagging cost, biaya perniagaan, alokasi produk dan tarif jasa giling semen. Pada perhitungan NPV awal diberikan base tarif jasa giling semen sebesar Rp 304.000,-/ton semen, sama dengan base tarif jasa perhitungan manfaat ekonomis untuk pihak ketiga. Nilai manfaat ekonomis keberadaan grinding plant bagi Perseroan dengan tarif Rp 304.000,-/ton semen sebesar Rp 877.048,(NPV, Juta).

\section{Uji Skenario Skema Negosiasi Tarif}

Tahap uji skenario skema negosiasi tarif dilakukan dengan one-way sensitivity analysis dimana dilakukan perubahan 
pada nilai base tarif jasa giling semen pada indikator manfaat ekonomis kedua pihak. Dari sudut pandang Perseroan, uji skenario skema negosiasi dilakukan dengan perhitungan NPV untuk dua kondisi yaitu NPV tanpa adanya grinding plant dan NPV adanya grinding plant dengan melakukan running model untuk mengetahui perubahan alokasi distribusi yang terjadi ketika tarif jasa giling semen dirubah. Dengan melihat indikator NPV, dilakukan analisis deviasi antara kedua kondisi tersebut. Uji skenario skema negosiasi tarif dari sudut pandang pihak ketiga dilakukan dengan menaikturunkan base tarif jasa giling semen pada analisis kelayakan grinding plant dengan indikator NPV.

Dari hasil uji skenario skema negosiasi, diperoleh feasible area tarif jasa giling semen yang menguntungkan bagi kedua belah pihak berada di antara Rp 304.000,- dan Rp 341.000,per ton semen. Berdasarkan Gambar 6 dapat dilihat bahwa semakin tinggi tarif jasa giling semen yang ditetapkan, maka nilai manfaat ekonomis bagi pihak ketiga juga akan semakin tinggi. Sebaliknya, semakin tinggi tarif jasa giling semen, maka nilai manfaat ekonomis bagi Perseroan akan semakin menurun. Batas bawah tarif diperoleh sebesar Rp 304.000,/ton semen karena tarif tersebut menghasilkan nilai NPV indikator kelayakan investasi grinding plant bagi pihak ketiga yang paling mendekati nol, yaitu Rp 941,- (Juta). Sedangkan batas atas tarif jasa giling semen diperoleh Rp 341.000,-/ton semen karena tarif tersebut menghasilkan nilai NPV incremental benefit bagi Perseroan yang paling kecil atau paling mendekati nol, yaitu Rp 8.581,- (Juta).

Win-win solution diperoleh dengan melihat titik keseimbangan, dimana titik keseimbangan merupakan titik yang memiliki simpangan sama dengan nol. Dalam kasus ini, win-win solution dengan kata lain merupakan tarif jasa giling semen yang menghasilkan nilai perbedaan (delta) manfaat ekonomis bagi kedua belah pihak yang mendekati nol. Dari hasil perhitungan, diperoleh win-win solution tarif jasa giling semen sebesar Rp 328.000,-/ton semen. Dengan delta manfaat ekonomis antara kedua belah pihak diperoleh sebesar Rp 7.377,- (NPV, Juta).

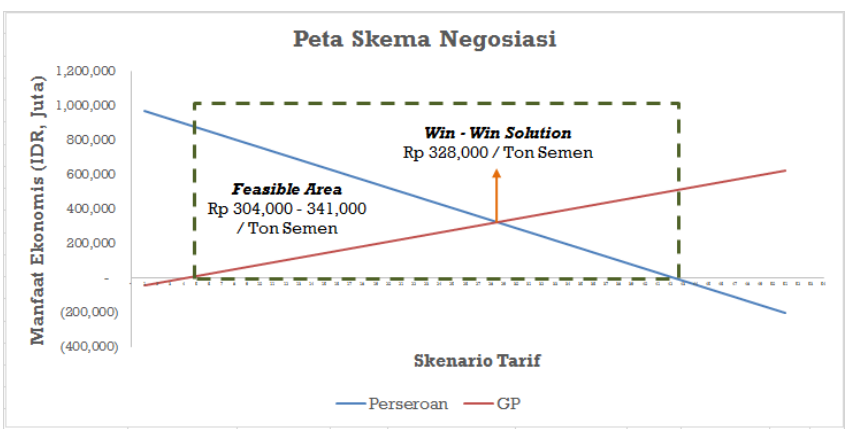

Gambar. 6. Peta Skema Negosiasi Tarif Jasa Giling Semen.

\section{E. Uji Sensitivitas}

Dilakukan uji sensitivitas beberapa faktor yang berpengaruh terhadap penentuan titik tengah tarif jasa giling semen. Terdapat 17 faktor yang dapat menggeser posisi winwin solution tarif jasa giling semen dari titik semula. Uji sensitivitas dilakukan dengan menerapkan one-way sensitivity analysis. Dengan kata lain, menaikturunkan nilai dari faktor tertentu kemudian melihat pengaruhnya terhadap indikator yang ingin dilihat, yaitu titik tengah tarif jasa giling semen. Nilai dari faktor-faktor lainnya dianggap tetap menggunakan nilai base.

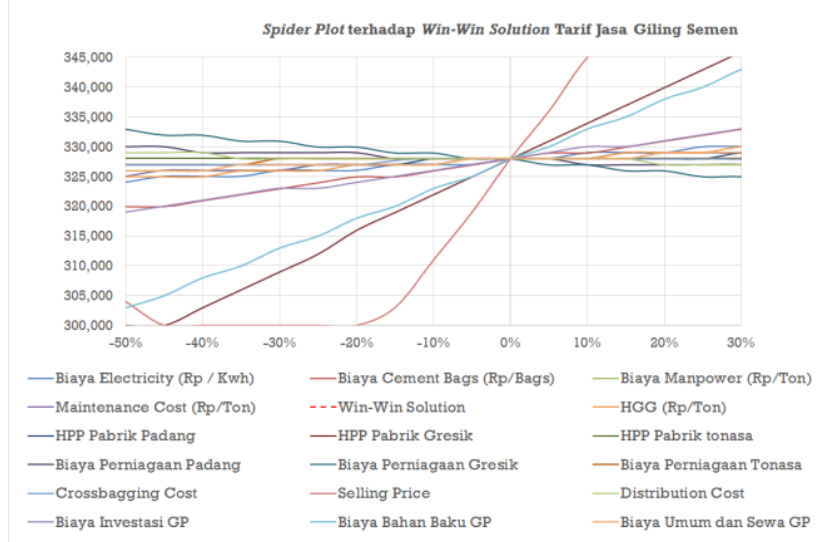

Gambar. 7. Spider Plot terhadap Win-Win Solution Tarif Jasa Giling Semen

Selanjutnya faktor-faktor tersebut diurutkan untuk melihat faktor mana yang memiliki pengaruh paling besar terhadap titik tengah tarif jasa giling semen. Urutan faktor yang mempengaruhi titik tengah tarif jasa giling semen yaitu [1] HPP Pabrik Gresik, [2] Selling Price, [3] Biaya Bahan Baku di GP, [4] Biaya Investasi GP, [5] Biaya Cement Bags, [6] Biaya Perniagaan Gresik, [7] Biaya Electricity, [8] Biaya Hot Gass Generator, [9] Biaya Maintenance, [10] Biaya Manpower, [11] Biaya Perniagaan Padang, [12] Biaya Umum dan Sewa GP, [13] Crossbagging Cost, [14] HPP Pabrik Padang, [15] Distribution Cost, [16] Biaya Perniagaan Tonasa, [17] HPP Pabrik Tonasa.

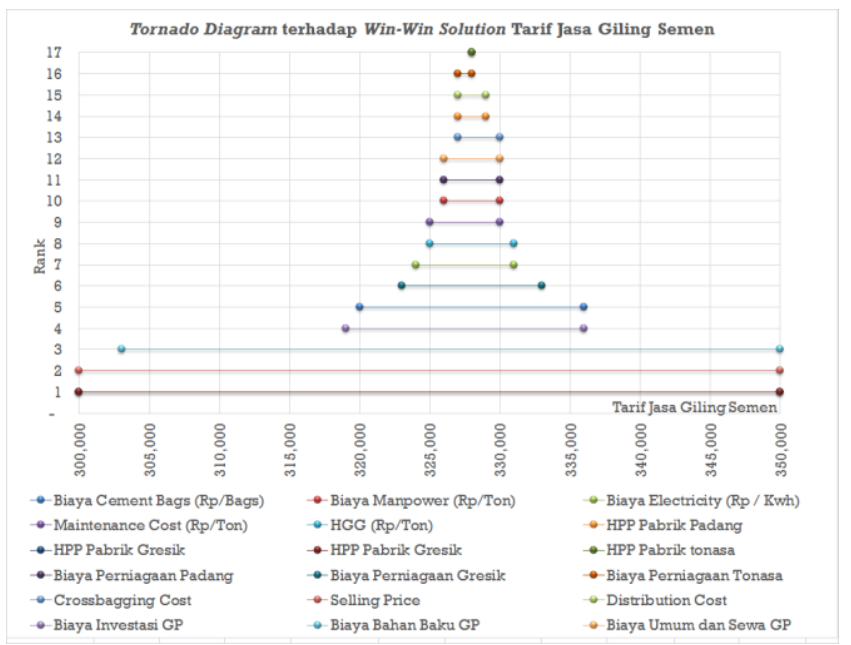

Gambar. 8. Tornado Diagram terhadap Win-Win Solution Tarif Jasa Giling Semen

\section{HASIL DAN PEMBAHASAN}

Hasil dari uji skenario skema negosiasi menunjukkan titik keseimbangan tarif jasa giling semen antara Perseroan dengan pihak ketiga berada pada Rp 328.000,-/ton semen. Nilai manfaat ekonomis keberadaan grinding plant bagi pihak ketiga dengan tarif Rp 328.000,-/ton semen diperoleh indikator kelayakan NPV sebesar Rp 321.095,- (Juta), IRR $16,848 \%$ dan payback period 8 tahun 10 bulan.

Running model untuk perhitungan manfaat ekonomis keberadaan grinding plant bagi Perseroan dilakukan setiap 
kali terjadi perubahan tarif pada perancangan skema negosiasi tarif karena adanya perubahan tarif akan merubah alokasi distribusi pada Perseroan. Dari hasil uji skenario skema negosiasi serta enumerasi running model optimasi, diperoleh win-win solution tarif jasa giling semen sebesar $\mathrm{Rp} 328.000,-/$ ton semen dengan nilai incremental benefit $\mathrm{Rp}$ 313.718,08 (Juta). Berdasarkan hasil dari running software model optimasi untuk kondisi dengan adanya grinding plant, diperoleh bahwa pemasok clinker terbaik ke grinding plant merupakan Pabrik Gresik. Hal ini dikarenakan, dibandingkan dengan ketiga pabrik lainnya, Pabrik Gresik memiliki HPP dan biaya distribusi dari pabrik ke grinding plant yang relatif lebih rendah

Perseroan memperoleh incremental benefit keberadaan grinding plant disebabkan oleh adanya efisiensi penggunaan clinker di grinding plant. Pemanfaatan slag powder sisa dari Krakatau Posco mampu menghemat penggunaan clinker dari yang awalnya 1 ton clinker dapat menghasilkan 1,25 ton semen, naik menjadi menjadi 1,82 ton semen. Untuk menghasilkan jumlah semen yang sama, Perseroan dapat menghemat biaya pengolahan quarry ke clinker sebesar 45 $\%$ apabila clinker dipilih untuk diolah di grinding plant. Efisiensi penggunaan clinker juga menyebabkan penambahan jumlah semen yang diproduksi hingga mencapai $45 \%$. Hal ini berujung pada peningkatan keuntungan (profit) dikarenakan adanya peningkatan jumlah produk yang bisa dijual ke market dan penghematan biaya produksi.

Benefit strategic yang bisa diperoleh Perseroan dengan menerapkan usulan skema bisnis salah satunya adalah sebagai usaha dalam meminimalisir risiko investasi pembangunan grinding plant dan memenuhi kebutuhan pendanaan. Hal ini dikarenakan, kelayakan investasi grinding plant dipengaruhi oleh banyak faktor ketidakpastian, seperti distribution cost, production cost, selling price dan demand nasional. Selain itu, Perseroan saat ini telah dan sedang merealisasikan berbagai program pengembangan usaha melalui beragam kegiatan investasi. Perseroan memandang perlu adanya penggalian sumber dana eksternal, dalam batas-batas yang layak, agar kegiatan pendanaan memberikan keuntungan optimal dalam jangka pendek dan jangka pendek serta memenuhi kebutuhan pendanaan dalam rangka pengembangan investasi yang dilakukan.

Salah satu tujuan dari penelitian adalah merancang range rekomendasi strategi negosiasi tarif jasa giling semen yang feasible antara Perseroan dan pihak ketiga. Perlu dilakukan uji skenario skema negosiasi terhadap tarif jasa giling semen. Range tarif jasa giling semen yang digunakan dalam uji skenario skema negosiasi bernilai antara Rp 300.000,/ton semen hingga $\mathrm{Rp} 350.000$,-/ton semen dengan eskalasi sebesar 4,5\% setiap tahunnya. Uji skenario menghasilkan skema negosiasi tarif jasa giling semen feasible pada range tarif Rp 304.000,-/ton semen hingga Rp 341.000,-/ton semen. Titik keseimbangan (win-win solution) terjadi pada tarif jasa giling semen sebesar Rp 328.000,-/ton semen dengan nilai manfaat ekonomis (NPV) Perseroan sebesar Rp 313.718,- (Juta) dan nilai manfaat ekonomis (NPV) pihak ketiga sebesar Rp 321.095,- (Juta). Dengan mengetahui titik keseimbangan, maka akan lebih mudah menentukan skema negosiasi tarif jasa giling semen yang akan diambil oleh Perseroan dan pihak ketiga.

Titik keseimbangan hanya digunakan sebagai salah satu pertimbangan dalam penentuan tarif jasa giling semen yang sebaiknya diambil oleh Perseroan dan pihak ketiga, tidak mutlak harus digunakan. Hal ini dikarenakan, dengan tarif sebesar Rp 328.000,-/ton semen, pihak yang lebih diuntungkan merupakan pihak ketiga karena memperoleh nilai manfaat ekonomis Rp 7.377,- (Juta) lebih banyak dari Perseroan. Risiko yang dapat terjadi adalah kondisi dimana Perseroan tidak terima apabila menjadi pihak yang kurang diuntungkan. Sehingga, penentuan tarif bisa bergeser menjadi Rp 327.000,-/ton semen, dimana Perseroan lebih diuntungkan dengan nilai manfaat ekonomis Rp 29.436,(Juta) lebih banyak dari pihak ketiga. Kondisi lain, tarif naik menjadi Rp 329.000,-/ton semen dimana pihak ketiga lebih diuntungkan dengan NPV Rp 44.189,- (Juta) lebih banyak dari Perseroan. Pergeseran ini tergantung dari pihak mana yang mau mengalah.

\section{KESIMPULAN DAN SARAN}

Usulan skema bisnis muncul dalam upaya untuk meminimumkan risiko pembangunan grinding plant dan memenuhi kebutuhan pendanaan investasi grinding plant melalui sumber dana eksternal (pihak ketiga) bagi Perseroan. Beberapa risiko yang mungkin muncul dari adanya usulan skema bisnis diatur dalam bentuk perjanjian antara kedua belah pihak.

Perhitungan manfaat ekonomis keberadaan grinding plant dari perspektif pihak ketiga menggunakan NPV indikator kelayakan. Sedangkan perhitungan manfaat ekonomis keberadaan grinding plant dari perspektif Perseroan menggunakan NPV incremental benefit.

Skema negosiasi tarif jasa giling semen yang feasible terdapat pada range tarif Rp 304.000,-/ton semen hingga Rp $341.000,-/$ ton semen. Titik keseimbangan (win-win solution) terjadi pada tarif jasa giling semen sebesar Rp 328.000,-/ton semen dengan nilai manfaat ekonomis (NPV) Perseroan sebesar Rp 313.718,- (Juta) dan nilai manfaat ekonomis (NPV) pihak ketiga sebesar Rp 321.095,- (Juta). Titik keseimbangan hanya digunakan sebagai salah satu pertimbangan dalam penentuan tarif jasa giling semen yang sebaiknya diambil oleh Perseroan dan pihak ketiga, tidak mutlak harus digunakan. Pergeseran tarif tergantung dari pihak mana yang mau mengalah dengan memperoleh nilai manfaat ekonomis (NPV) lebih sedikit dibandingkan dengan pihak lainnya.

\section{UCAPAN TERIMA KASIH}

Puji syukur penulis panjatkan kepada Allah SWT atas segala rahmat dan hidayah-Nya sehingga penulis dapat menyelesaikan penelitian dengan lancar. Terima kasih juga penulis ucapkan kepada orang tua penulis, yang senantiasa memberikan dukungan dan semangat kepada penulis. Dosen pembimbing, Bapak Yudha Andrian Saputra, S.T., MBA yang selalu menginspirasi dan dengan sangat sabar membimbing dan memberikan arahan selama pengerjaan 
penelitian. Terima kasih juga penulis ucapkan kepada pihakpihak yang tidak bisa disebutkan satu persatu.

\section{DAFTAR PUSTAKA}

[1] Anityasari, M. \& Wessiani, N.A., 2011. Analisa Kelayakan Usaha Dilengkapi Kajian Manajemen Resiko. Surabaya (Jawa Timur): Guna Widya.

[2] Antika, M. A. (2014). Model Alokasi Semen di PT Semen Indonesia (Persero) Tbk Untuk Perencanaan Pendirian Pabrik Baru, Pabrik Penggilingan dan Pabrik Pengantongan.

[3] Assegaf, A., 2001. Kamus Akuntansi. Jakarta: PT Mario Grafika.

[4] Daellenbach, H.G. dan McNickle, D.C. (2005). Management Science: Decision Making Through System Thinking. New York: PALGRAVE MACMILLAN.

[5] Erika, Vincentia. (2016). Pengembangan Konsep Investment Feasibility Tracking and Forecasting System untuk Mengevaluasi Keberhasilan Project Life Cycle.

[6] Gass, L.I. dan Assad, A.A. (2005). An Annotated Timeline of Operations Research: An Informal History. Boston: Kluwer Academic Publishers

[7] Hasset, K. A., 2008. Investment. s.1.:s.n.

[8] Holcim Indonesia, 2013. Holcim Capai Pertumbuhan Laba 27\% dan Pertumbuhan Penjualan 20\% di Tahun 2012. [Online] Available at: http://www.holcim.co.id/id/media/siaran-pers-terbaru/latestrelease/article/holcim-capai-pertumbuhan-laba-27-dan-pertumbuhanpenjualan-20-di-tahun-2012.html

[Diakses 24 Februari 2016]

[9] Ikatan Akuntan Indonesia. 2007. Pendapatan.

[10] Indocement, 2016. Penjualan dan Pemasaran. [Online] Available at: http://www.indocement.co.id/v5/id/company/business/salesmarketing/ [Diakses 24 Februari 2016]

[11] International Trade Center, 2016. Contract of Carriage: FOB, $C I F / C F R$, FOT and FCA. [Online] Available at: http://www.intracen.org/default/aspx [Diakses 8 Maret 2016]

[12] Kementrian Pendidikan dan Kebudayaan, 2016. Kamus Besar Bahasa Indonesia Online. [Online] Available at: http://kbbi.web.id [Diakses 8 Maret 2016]

[13] Khoong, C. \& Ku, Y., 1994. A Holistic Feasibility Study Framework for Decision System. IEEE Transactions on System, Manm and Cybernetics, 24 (1), pp.100-106.

[14] Khurdi, Nughthoh Arfawi. 2013. Riset Operasi Probabilistik Teori Permainan (Game Theory), Surabaya, FMIPA UNS.

[15] Observation and Research of Taxation (Ortax), 2007. Penyusutan (Bagian Pertama). [Online] Available at: http://www.ortax.org/ortax/?mod=studi\&page=show\&id=51 [Diakses 20 Juni 2016]

[16] Pratiwi, V. N. (2014). Penentuan Skema Negosiasi Bisnis LPG Plant Dengan Pihak Ketiga.

[17] PT Semen Indonesia (Persero) Tbk, 2013. Brand Equity yang Semakin Kokoh dan Pangsa Pasar Domestik Terbesar. [Online] Available at: http://www.semenindonesia.com/page/read/brandequity-yang-semakin-kokoh-dan-pangsa-pasar-domestik-terbesar2634 [Diakses 24 Februari 2016] 